\title{
Towards an interpretative model of Mexcaltitan in the insular universe. First approximation
}

\section{Hacia un modelo interpretativo de Mexcaltitan en el universo insular. Primera aproximación}

\author{
SIFUENTES-SOLÍS, Marco †* \& GONZÁLEZ-LEFFT, Gabriela
}

Universidad Autónoma de Aguascalientes, Centro de Ciencias del Diseño y de la Construcción

ID $1^{\text {st }}$ Author: Marco, Sifuentes-Solís / ORC ID: 0000-0002-1110-568X, CVU CONACYT ID: 202779

ID $1^{\text {st }}$ Coauthor: Gabriela, González-Lefft / ORC ID: 0000-0003-4633-9360, CVU CONACYT ID: 422903

DOI: $10.35429 / \mathrm{EJS} .2020 .12 .7 .28 .43$

Received January 18, 2020; Accepted June 28, 2020

\begin{abstract}
The generation of knowledge on the specific topic of the island of Mexcaltitan de Uribe, Nayarit (Mexico) and its strange and no less mysterious urban trace, can be approached from at least two major fields of vision: 1) from the objective / subjective, individual / collective residents (egocentric communities); 2) from the objective / subjective, individual / collective view of nonresident aliens (exocentric communities). As researchers, in this article we adopted the second point of view, with the aim of constructing (as an input) a first approximation to the study of the urban trace of that singular place. For this, we resorted to two theoretical models and their application to the analysis of the space referred to: symbolic hermeneutics and the anthropological structures of the imaginary. The main contribution of the text lies precisely in the approach of the problem from the previous theoretical and methodological background, unusual in the academic field of architects and urban planners.
\end{abstract}

Mexcaltitan, Egocentric / exocentric communities, Anthropological structures of the imaginary

\section{Resumen}

La generación de conocimiento sobre el tema específico de la isla de Mexcaltitán de Uribe, Nayarit (México) y su extraña y no menos misteriosa traza urbana, puede abordarse desde al menos dos campos de visión principales: 1) desde el campo objetivo / subjetivo de residentes particulares / colectivos (comunidades egocéntricas); 2) desde el campo objetivo / subjetivo, de visitantes foráneos particulares / colectivos (comunidades exocéntricas). Como investigadores, en este artículo adoptamos el segundo punto de vista, con el objetivo de construir (como insumo) una primera aproximación al estudio de la traza urbana de ese lugar singular. Para ello, recurrimos a dos modelos teóricos y su aplicación al análisis del espacio referido: la hermenéutica simbólica y las estructuras antropológicas del imaginario. La principal contribución del texto radica precisamente en el enfoque del problema desde los antecedentes teóricos y metodológicos anteriores, inusual en el campo académico de los arquitectos y urbanistas.

Mexcaltitán, Comunidades egocéntricas / exocéntricas, Estructuras antropológicas de lo imaginario

Citation: SIFUENTES-SOLÍS, Marco \& GONZÁLEZ-LEFFT, Gabriela. Towards an interpretative model of Mexcaltitan in the insular universe. First approximation. ECORFAN Journal-Spain. 2020. 7-12: 28-43.

\footnotetext{
* Correspondence to Author (email: lgarza@upgop.edu.mx)

$\uparrow$ Researcher contributing first author.
} 


\section{Introduction}

In 1986, the Island of Mexcaltitan was declared as a Zone of Historical Monuments by means of a presidential decree issued in the Official Gazette of that year; the arguments put forward made it an object of ideological sacralization and therefore its ordered protection. In 2001 it was declared as Pueblo Magico, a distinction lost in 2009 for reasons not entirely clear.

The oral tradition, fed and distorted by the Mexican State and its institutions, has maintained the persistent idea that the island is the "Cradle of Mexicanness" 2 for allegedly being the mythical place Aztlan, from where the Aztecs (and with them, Xochimilcas, Chalcas, Tepanecas, Acolhuas, Tlahuicas and Tlaxcaltecas) left to found, after a journey of more than two hundred years, the powerful Mexican empire and the great capital that was eventually Tenochtitlan, an idea that the French geographer and urbanist Jérôme Monnet was brilliantly responsible for unmasking, denouncing that such an approach is part of the integration of the State to a symbolic geography of Mexicanness: Mexcaltitan and Aztlan thus became "federal centralist symbols that concentrate the nation around its only common denominator, the State"; Mexicanness, in this way, "ends up being at the same time a monument from the State".

Thanks to the mythification, the margin (Mexcaltitan, the poor but glorious periphery) becomes "the alpha of nationality, the matrix, the imaginary metropolis, counterweight to the real metropolis" (Mexico City, seat of central power). Mexcaltitan is emblematic "of the transmutation of history into myth and from space in symbol", which the State performs "for the interest of the center, which is also its own". ${ }^{3}$ But what does Mexcaltitan represent for its inhabitants, for tourists, for other communities of bronco or subdued Mexico? Its urban trace, so peculiar, to which set of meanings can be attributed? Are they all aware of the patrimonial or mythical values attribuited to Mexcalitan for the Mexican State? What does it mean in the subjectivity of these people to be an island, to be a mythical geography? What does it mean to outsiders?

\footnotetext{
${ }^{1}$ I especially thank Irma Leticia Medina for a first syntactic review of this article.

${ }^{2}$ The term "Mexicanness" refers to a kind of rhetorical figure of the birth and identity definition of a race, such as the Mexica or Aztec, as the metonymy of an entire nation, in this case the Mexican one (Romero, 1989: p.6). Its constitution as such is the product of stories instituted rather from the reinvention of myths of origin made by secondary sources, often with political-ideological aims, as Monnet (1991: 25) has shown.

If Monnet is interested in demonstrating "why Mexcaltitan is Aztlan in today's Mexico", what our work adds is a dimension little explored: that of the urban trace of Mexcaltitan as a material expression of a constellation of meanings that leads to linking it with longstanding island archetypes. In this direction, the hypothesis that underlies in our discourse, that does not pursue aims of verification but rather of abductive exploration, is, from a very preliminary exocentric perspective, that the curious urban trace of that town, reveals to us as an aspect with at least one dimension that links it to myths that keep common imaginary patterns related to the universal island culture, with some historical basis, since it is doubtful that this route (most probably from viceregal times) was the work of chance or spontaneity; on the contrary, everything suggests that it follows a premeditated design. Whoever had been the author (it is also doubtful that it was the work of many individuals), it would not be entirely unreasonable to have known, read and assimilated the geographic-literary genre of the medieval and renaissance islars, and even to be categorically proved it did not feed on other indigenous mythical counter-narratives (for example, Huichol); suppositions which, for the moment, we are unable to verify.

In this article we then approach a first approximation, still incipient, incomplete and totally controversial, of a space or of a mythified geography -in the Monnet line- through the search and "putting into practice" of the most ideal theoretical model and the analytical perspective more fruitful to answer the previous questions in the project in which we are involved. Hence, it is restricted to a bibliographical revision of the island's theme and to the rudiments of a conceptual theoretical body that allows, in the future, to fit the empirical work in a framework in which field data makes full sense. Also, it reduces to an elemental analysis of the trace under the previous concepts and categories.

For this, we have chosen to direct our research by postulating a space of convergence in the precise crossing of three theoretical fields: symbolic hermeneutics, anthropology of the imaginary and the geography of interpretation.

${ }^{3}$ After considering the inconsistencies of the available evidence (which we will see later), this author is not interested in demonstrating why Mexcaltitan is not Aztlan, but precisely "why Mexcaltitan is Aztlan in today's Mexico", that is, what lies behind the persistent idea on placing it as the cradle of Mexicanness (Monnet, 1991: 2539; Monnet, 1995: 287-318).

SIFUENTES-SOLÍS, Marco \& GONZÁLEZ-LEFFT, Gabriela. Towards an interpretative model of Mexcaltitan in the insular universe. First approximation. ECORFAN Journal-Spain. 2020 
The first, in the sense of positioning Mexcaltitan in a more general frame of discussion around the insular universe. The second is to interpret the urban trace of the island, in a mythological frame, and the third is interested in understanding how they conceive and what meanings give to this geographical territory different communities of subjects, both residents and foreign visitors (tourists or ethnic groups), from the processes of subjective construction of their relationship with the island, with the layout and in general with the urbanarchitectural heritage, which is the framework built in where they develop their life; that is to say, in ethnographic terms. In the last part of the text, we began to immerse ourselves in that space, through a first analysis of the urban trace of Mexcaltitan as a pretext to better understand the theatre where they are produced or from which narratives and counter-narratives are reinvented, whose interpretation will be a matter of other deliveries. For now, we must be content with this, given that the project is just underway.

\section{The theme of the island in the universal island imagination}

In a relatively recent text, Georgeos DiazMontexano (2014), from the Scientific Atlantology International Society, has stated forcefully that "There is no connection between Aztlan and Atlantis". And in many ways he is right. We do not intend here to oppose any thesis or argument of a geological, archaeological, philological, epigraphic, lexicological or even historical character against this statement, but rather to point out that in another sense there is at least one dimension that links them to myths that keep common imaginary patterns, with some historical basis, but also to mythical imaginaries exploited by non-scientific literature. That is why we wanted to start with a brief development of the island theme as a mythical imaginary.

From symbolic hermeneutics, throughout the history of the cities, insula has been a topic that has occupied the imagination and pen of not only a few writers. The prototypical or archaeo-prototypical case is that of the "lost continent" of Atlantis, in whose bosom a society and culture of wise and technologically advanced humans flourished in the time, whose capital was established as the centre of an "island-peninsula" (Atlantís nêsos).

${ }^{4}$ Without author, "Atlantis in the «Dialogues» of Plato.

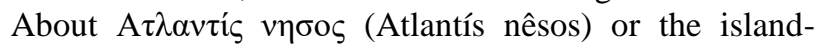
peninsula of Atlantis", at: http://www.culturandalucia.com/TARTESOS/PLATON_ DIALOGOS_CRITIAS_ATLANTIDA.htm. Consult: May 28, $201 \overline{7}$.

ISSN: 2444-3204

ECORFAN ${ }^{\circledR}$ All rights reserved
Based on Plato's writings, hypothetical reconstructions suggest that this nucleus was surrounded by three concentric ports, two land areas and a citadel, in a total diameter of almost $5 \mathrm{~km}$; in these last three areas there were several inhabited spaces, already open, already closed, as well as temples, palaces and acropolis such as gymnasiums, racecourses, gardens, woods, fountains, monuments, military barracks, common rooms, harbours, bridges, docks, canals, aqueducts. Plato himself, in the dialogue of the Laws, conceived the city of Magnesia with a circular arrangement consisting of seven concentric circles whose radii were obtained from the harmonic progression resulting from multiplying the series $1,2,3,4,5,6,7$ as follows: $1 \cdot 1=1 ; 1 \cdot 2=2 ; 2 \cdot 3=6 ; 6 \cdot 4=24$; $24 \cdot 5=120 ; 120 \cdot 6=720 ; 720 \cdot 7=5,040$; that latter number was ideal for the population foreseen and for the number of lots (Navarro, 2016: 23-24; Muñoz, 1991). Assuming that the radius of the central circle measured 1 stadium (the first digit of the previous series), its diameter would therefore be equivalent to 2 stadia, that is, approximately $400 \mathrm{~m}$, which is the long diameter of the island of Mexcaltitan.

It is speculated that the great island Atlantis could have been located in the Mediterranean, although also it has been located in the Atlantic (which is most likely), while fantastic theories of improbable sites abound, provoked by the relatively absence or lack of documented certainties and verifiable vestiges.

Plato, in his Dialogues, picked up, second-hand, an old legend that went from mouth to mouth in a retro-chain that ran from Critias to his grandfather, and from him to Athenian politician Solon, who in turn transmitted Egyptian priests from the Nile delta. According to this tradition, origin of the mythical kingdom went back up to nine thousand years before the mentioned dialogue, ${ }^{4}$ some even speak of twelve thousand, ${ }^{5}$ resulting in an incredible earlier date even to the dawn of the earliest civilizations in Sumer and Egypt (Killuminati, 2013).

Whatever it is, the truth is that in the Dialogue, Critias relates that in times immemorial the gods divided among themselves the world, belonging Poseidon the island territory of Atlantis.

${ }^{5}$ Without author, "Civilization and the lost continent of Atlantis", in: http://www.borala.site/continente-perdidode-atlantida. Consult: June 23, 2017.

SIFUENTES-SOLÍS, Marco \& GONZÁLEZ-LEFFT, Gabriela. Towards an interpretative model of Mexcaltitan in the insular universe. First approximation. ECORFAN Journal-Spain. 2020 
He married a mortal, Clito, who lived on a hill on the island, which Poseidon soon proceeded to fortify, so that "he isolated her from everything that surrounded her. He made walls and moats with earth and water of the sea alternately, some smaller, some larger, two of earth and three of water, occupying the centre of the island, so that all its parts were at an equal distance from the same". 6 This last description confirms, as in fact Critias manifests it almost explicitly, that the island within the island, that is to say, the "isolated island that embodies the semantic tautology of insularity" (Ainsa, 2000: 7), had a circular shape, furrowed by the three moats and the two areas of land, which reserved the centre for the citadel. If this happened or not, it is something that archeology (probably underwater, given that in Plato's time it was said that this island continent had sunk after earthquakes and other calamities) should elucidate it; but what is important, for our purposes, is the fable of an island within another island, a beautiful metaphor of the relationship between interiority, exteriority and centrality, finally, between the ego and the alter, between the own and the other.

For all the above, it would be little less than a sterile exercise to wear out in the eternal discussion about the true geography of Atlantis. On the other hand, it is another type of geography that we are interested in discussing here: "mythical geography", the invention and reinvention of a myth of which there are many parallels in ancient cultures or, as Fernando Ainsa says, mythology island, which although it was founded in classical Greece, was until the thirteenth century AD when "popular belief is widespread that the most spectacular wonders and most exotic lands are in mysterious and distant islands" (Ainsa, 2000: 9); in short, our focus is the metaphorical subjectivization of the island condition, not without the idyllic connotations of a lost golden and quasi-edenic age: Atlantis would be the archetype of the island (any island), in which a symbiotic relationship is established between the inside and the outside, or the closed and the open (Punte, 2013: 117), but from the tension established with a centre, with the knowing and feeling centre, as well as, in this same tenor, had already noted Frank Lestrignant (quoted at Pellicer, 2000: 355).

\footnotetext{
${ }^{6}$ Without author, "Civilization and the lost continent of Atlantis", in: http://www.borala.site/continente-perdidode-atlantida. Consult: June 23, 2017.

${ }^{7}$ An acceptable discussion of cultural prejudices about "the Other" can be found in Gracia (2000: 283-296).

${ }^{8}$ For Martinez (1997: 20-21), a mythical island is that "in which the myth plays an important role in its history or in which a certain myth develops completely".

ISSN: 2444-3204

ECORFAN ${ }^{\circledR}$ All rights reserved
}

Atlantis as a golden kingdom, Avalon as a mythical island ${ }^{8}$ of the Arthurian legend, Aztlan as a primitive island, Mexcaltitan as "center of Mexicanness", Tenochtitlan as the navel of the world, Utopia as unrealistic fantasy. Cosmos -order- and chaos: the centre (the city, the island) "will be a harmonious cosmos, outside of which is the nature in the middle of which man loses and succumbs" (Iriarte, 2005: 24).

Is it the fear of the alien, the strange, the non-proper that governs the insularization of existence, real or imaginary, as Iriarte (2005: 27) seems to suggest? Mario Tome (1987: 15) points out that from ancient times "the island has been a continuous object of human attention". If the symbol, he says, "is a «meeting place» in which a representation or physical entity, with an «incomprehensible content - invisible, unspeakable and trans-conscious», the island is revealed as such"; thus, the symbol of the island "appears as an enigma that man must decipher to know himself" (Tome, 1987: 17). According to this author, among the many authors who have worked on the island as a theme, seven basic contents can be extracted and this are the island as a primordial spiritual centre; as a paradisiacal space; like another world or beyond wonderful; as a microcosm; as a land of utopia; as the shelter; or as the conjunction "island-woman" or "shipwreck-island" (Tome, 1987: 18). ${ }^{9}$

It is curious but revealing that in the myths of origin or in the imaginary of sacred or foundational texts the Hereafter appears surrounded by water, or that the "cities of immortality" of mythology and religion are separated from the mainland, united by some element that allows the passage to them. Thus, Tome refers to various examples around the ancient world: the city of the willows in the Chinese tradition; to the White Island (Swetadvipa) of the Kurma Purana; to Syria among the Greeks, to which "it could be identified with the Hyperborean Thule"; or to the island of Leuke in Greek mythology, the immortal abode of Achilles, or in the end, in this same tradition, to the Island of the Lucky.

${ }^{9}$ From the literary field, Cristina Peri Rossi (2000: 382) ventures that there are at least three main allegories about the islands: a) as paradise or utopia; b) imprisonment, exclusion, marginalization, exile or estrangement; c) as interiority, ultimate redoubt of subjectivity, inalienable space of the self.

SIFUENTES-SOLÍS, Marco \& GONZÁLEZ-LEFFT, Gabriela. Towards an interpretative model of Mexcaltitan in the insular universe. First approximation. ECORFAN Journal-Spain. 2020 
Among the Celts would be Sidh, but also the island to which San Brandan arrived, as well as the Green Island; in Arthurian legend the aforementioned Avalon; and Montsalvat, the mountain in the middle of the sea of the legend of the Grail; in Islam also emerged the topic of the Green Island in the White Sea, whose description paints it like a walled circle that protects a city (Tome, 1987: 24-28).

Other accounts are the supposed voyage of Yambulo (counted by Diodorus in the first century BC) to the "marvelous" Islands of the Sun in the Indian Ocean, one of which "was round in shape and had a perimeter of almost five thousand stadia", that is to say, a territorial extension not negligible, taking into account that these five thousand stadia would equal to thousand kilometers in circumference (Fernandez, 2010: 35). Also, that of the "wandering islands" of the Greek Mediterranean, inserted in a mythological framework approached by Moret (2011 / 2012: 455-464), by which this author finds that this phenomenon is presented in several ancient stories that share four archetypal elements reproducible as mythical schemes: a "wandering" island, a god that fixes it to the base of the world and makes it habitable, a serpent and a fountain (Moret, 2011 / 2012: 459). Note the parallelism with the foundational myth of Tenochtitlan; likewise, notice the one of Mexcaltitan, that is extremely similar to the opinion maintained by Achilles Tacitus, in $2^{\text {nd }}$ century AD, about the island of Tire, which gave the "strange spectacle of a city on the sea and an island on earth" (Moret, 2011 / 2012: 462). Keeping the proportions, the building density of Mexcaltitan, occupying the whole island, and its proximity to the banks of the lagoon that surrounds it, which although it is part of the national marshes, is still close to the mainland, bring it very close to the expression of Achilles. ${ }^{10}$

Marcos Martinez (2010: 55-74) has worked on the topic of legendary islands both in history and in literature, distinguishing them from the utopian islands, mythical or even what he calls "ghosts". 11

\footnotetext{
${ }^{10}$ The marshes represent an aquatic world that simultaneously "is not sea but not earth", and yet, following the mythical logic of the huicholes about opposites that are both one, it is sea and it is land: symbolically it is a village "in the sea", that is to say island surrounded by water, and "an islet" among the marshes, surrounded by land (Neurath and Pacheco, n.d.: 5).

${ }^{11}$ See also Martinez (1997: 19-43). A critical work in this line is Cruz (1994: 241-245).

ISSN: 2444-3204

ECORFAN ${ }^{\circledR}$ All rights reserved
}

Montesdeoca (2000: XXXIV), in his introductory note to the genre of geographical literature called Islars, focused in particular on the analysis of De insulis, by Domenico Silvestri ( $14^{\text {th }}$ century, first model of Islars), adds to this typology the cases of floating and paradisiacal or imaginary (Montesdeoca, 2000: XI), which may well correspond with the wanderers of Moret and Martinez, respectively. Montesdeoca (2000: $\mathrm{XI}$ ) also informs us that the sixth chapter of the $14^{\text {th }}$ book of the Etymologies, by Isidore of Seville ( $7^{\text {th }}$ century AD), "is considered the most systematic exposition of insular geography of Antiquity", although we also know of an islar made in 1560 by Alfonso de Santa Cruz (Ö̈ffer, 2011: 99-128).

The introductory study of Montesdeoca is, so far, the most complete we have consulted.

In the Utopian tradition, adds Tome, "the island is the geography par excellence"; Trousson, quoted by Tome, warns that the most obvious and common external characteristic of utopia is its insularism, with the addition of involving the construction of a miniature society, in which, Tome (1987: 28) adds, "The need to move away from the real is imposed on the creator of utopias, who becomes an inventor of worlds in small, isolated from all corrosive contact with the outside" (Tome, 1987: 28) or, as Ainsa (2000: 13) affirms, "utopias will have the privileged stage of the islands and their primary vocation will be the «(isola)tion» and the autarchy that is adjudged as a virtue of uncontaminated purity", governed one and the other by a "will of insularity" and not a mere natural accident of geography.

Of course, the creative literature has not ceased to be attracted by the stimulating theme of the island topos, a field in which ink has also flowed generously, considering that this can be added to the four or five metaphors to which recurrent universal literature, one of which is water. $^{12}$

\footnotetext{
${ }^{12}$ As stated, following Jorge Luis Borges, Peri Rossi (2000: 379)
}

SIFUENTES-SOLÍS, Marco \& GONZÁLEZ-LEFFT, Gabriela. Towards an interpretative model of Mexcaltitan in the insular universe. First approximation. ECORFAN Journal-Spain. 2020 
In 1998 the Third Congress of the Spanish Association of Hispanic-American Literary Studies was organized on the island of Tabarca, in Alicante, where various papers were read, the main theme of which was "the possible island", focusing on "all dreams" literary writers who, in the Spanish-American tradition, had been fed by islands and, from them, "opened the congress in addition to correlative symbols that allowed anyone who did not have an island on hand to participate by metaphorizing their intervention on the island-city, island-eros, island-utopia, symbol of the last Thule, islandsalvation ... or any possible symbolic transformation" (Alemany et al., 2000: 6); in this tenor, some suggestive titles were: the geography of the isolation; the imaginary antiutopic insular; narrative and history of an island without sea; metaphors of the island; the different insula in the cosmos; drifting islands and floating identities; from the island to the cosmos; singular islands: Amazonas and Jauja; the inner island; in addition to many others related to poetry and narrative.

In obviousness of space, this very brief account should suffice, in which we must emphasize, following Fernandez Robbio (2010: 29), that the historiography (the utopian narrative), the mythology (the fantastic story) and the ethnography (the travel narrative) are mixed, and where the emergency zones of the symbol are: a) the phenomenology of religion; b) the universe of psychology; c) the world of creative imagination (Tome, 1987: 17).

\section{For the approach of the island: brief theoretical and methodological considerations}

If our project dealt with the cultural history of oral or written texts in which the idea of Mexcaltitan as the mythical Aztlan would have occurred, "our attention and interest in myths would have to shift from the hypothetical meaning of the text-from the inquiry about the diversity of its possible interpretations- to the description of the diversity of its effective actions", ${ }^{13}$ a route such that, in our case, we will not be able to continue in this first approximation for a reason as simple as the difficulty of having the relevant primary sources.
The choice we make, that is, our interpretation (one among that diversity of possible interpretations) of the hypothetical meaning of the island trace, will have to be confronted with the interpretation of the world and the order of it in the "effective actions" of various categories of social subjects (second approach), that is to say in the psychodynamic inter-determination between them in and with their environment.

So that, the comprehension and understanding of this topic has led us unfailingly to the orbit of the anthropological structures of the imaginary, the general archetype, the anthropological path and the symbolic imagination of Gilbert Durand (2000), but also, in the specific case of Mexcaltitan, to the geography of interpretation (Monnet, 2011: 135159).

If the first thing... for Durand the symbol is "a representation that makes appear a secret sense; is the epiphany of a mystery" (quoted by Ocampo, 2008: 36). His theoretical building generated the notion of an "anthropological journey", which consists of a dialectical coming and going between the subjective pulsations of the psyche (which connect with the nervous centres) and the objective situations that derive from the social environment (which derive in corporal gestures): this path would be the domain of culture and the process of symbolization (which becomes symbolic representations). In this way, the symbolic representation system implies the existence of three organizing structures of images: the schizomorphic structures (Diurnal regime of the images, or spatiality), the synthetic structures and the mystical structures (Nocturnal regime of the images). Each of these corresponds to certain dominant reflexes and schemes of action; to schizomorphs: distinguish, idealization, geometrism, antithesis (postural reflex); the synthetics: uniting, dramatization, historization and partial or total progress (copulative reflex); and the mystics: to confuse, redouble, viscosity, sensory realism and spraying (digestive reflex) (Ocampo, 2008: 34-40). Durand defines the scheme as "dynamic and affective generalization of the image", while archetypes constitute the "substantiation of schemata" or "expressions of certain mental instincts that unite the imaginary with rational processes" (Gracia, 2001: 144).

The diurnal regime "is linear time, and also the realm of light and the fear of darkness, for these are the expression of death as the end time".

\footnotetext{
${ }^{13}$ Walter Ong, quoted by Ekman (2009: 299) 
It is the regime of antithesis, of separation, of heterogeneity. While the nocturnal regime "is the cyclical time where death is assimilated in another way, through myths, rituals or stories that place this death on the side of initiation, learning, as a part of life. There is, therefore, euphemism of the night and this one is full of colors" (Ocampo, 2008: 40).

If the second ... one more analogy that allows us to connect our two theoretical devices: just as Mexcaltitan inhabitants are in themselves an "island" within their island, and as well as the street that circulates and delimits the interior of the island is inside from the island, to Monnet ${ }^{14}$ the human being "is in the middle of his environment" (of his fear too?), that is to say, he is in the environment, of which he forms part and is himself the environment of other beings (his microbes, for example), as long as the environment is considered "not as exteriority" or (solely and exclusively) as a world of objects. This requires Monnet to establish two modalities in the previous relationship: the subject-world orientation, where the individual "is a reality that acts in the world and transforms it effectively and materially"; and the world-subject orientation, in which the former "is a reality that the subject has to conceive and understand", which implies "analyzing how the subject" takes into account "the reality of the world, what is imposed on the subject" and even -we would say- how he realizes it and how he realizes that he realizes it. Thus, Monnet identifies two processes of the geographical performance of the subject: the interpretation of the world on the one hand, and the ordering of the same, on the other. The first is an ideal action "that influences the world only if the subject acts in the world" to transform it (a long-standing argument from Marx).

And dialectically, the world acts on the subject because it is still a biological entity governed also by the objective laws of Natura. It is, therefore, an inter-determination, since "a correct interpretation of reality guarantees the adaptation of the subject to his world, which is achieved when the subject manages to adapt the world to its objectives".

\footnotetext{
${ }^{14}$ All this section is a summary of Monnet (2011).

${ }^{15}$ Few years ago it was questioned what is called "exotic anthropology", that is to say, a discipline which, in order to avoid that the "«knowledge» produced about the investigated communities taking the form of locally unrecognizable representations that generally have minimal relevance to their modern difficulties", would require to be translated into concrete meaningful actions that improve living conditions in environments like Mexcaltitan. For a reconfiguring vision of the anthropological practice, see the notion "post-exotic anthropology" in Elie (2012: 1214).
}

ISSN: 2444-3204

ECORFAN $^{\circledR}$ All rights reserved
Following an idea of Monnet, one could ask if the different cultural groups that have been perpetuated in Mexcaltitan could do it because they incorporated their insular condition of isolation, their withdrawal, self-confinement, autarchy, marginality or their mythological identity as realities of their world. But why interpretation and not representation? ${ }^{15}$ This is because the second focuses on the mental images of the media objects of representations, while the first focuses on the "processes and actions that constitute the relationship with the world of individuals and groups in their respective livelihoods"; the ordering allows to reduce the field of human actions "to which they have as an objective or consequence the ordering of the means of life, including the individual scale to all the traditional scales of the geography". Thus, "Territorial or spatial organization realizes (real returns) an interpretation of the world" (italics in the original).

\section{A brief description of Mexcaltitan}

Given that the pre-Hispanic codices (such as the Boturini codex) do little to help describe Mexcaltitan (granting also its improbable identification with Aztlan), the earliest data available with which it is counted to characterize the site, was bequeathed to us by the chroniclers of the viceregal period. In historical cartography (for example in the Ortelius map, published in 1579 but apparently drawn around 1550) and in the Sum of visits, contemporary to this map, an "immense lake body" and four villages that "call all Mechuacan", among them "Mazcaltitlan", ${ }^{16}$ was mentioned. In the $17^{\text {th }}$ century Matias de la Mota spoke of the area as a region of estuaries and lagoons "that abounding waters, unite and make a sea grown", opinion also held by Wigberto Jimenez Moreno in the $20^{\text {th }}$ century. For M. Anguiano, "the inland waters that currently exist are, perhaps, the remains of a large lacustrine body", as a product of waterlogged fluvial, pluvial and maritime, whose fragmentation may have formed lagoons separated by these deposits (Anguiano, 1992: 29-30).

16 Rene Garcia Castro (2013: 138) clarifies that these villages were linked to Michoacan "Because fishes abound there, and fishers are the inhabitants", but not because they were part of the Michoacan region, much to the South.
SIFUENTES-SOLÍS, Marco \& GONZÁLEZ-LEFFT, Gabriela. Towards an interpretative model of Mexcaltitan in the insular universe. First approximation. ECORFAN Journal-Spain. 2020 


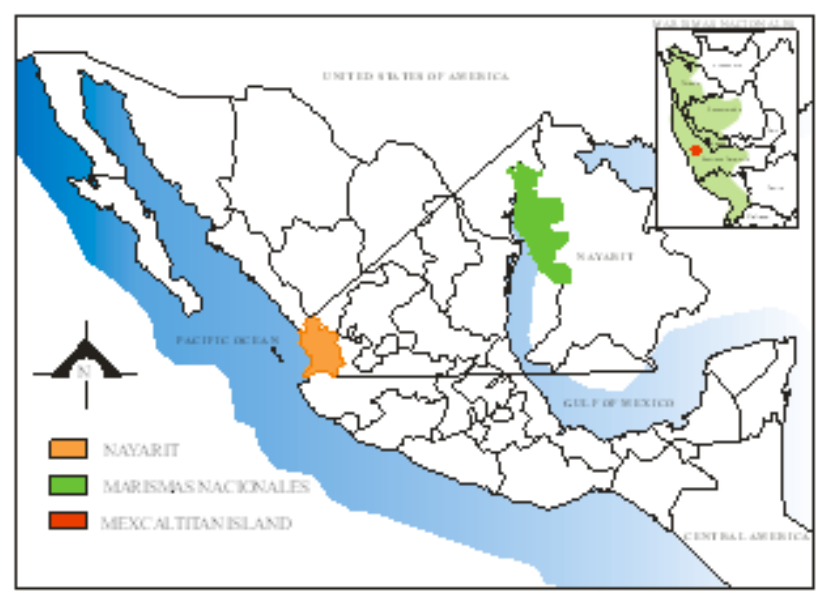

Figure 1 Geographic location of the Marismas Nacionales and the Island of Mexcaltitan, Nayarit

Source: self-made

Digital edition: Eduwiges Hernandez Becerra.

At present the island of Mexcaltitan is located on the coastal plain of the Pacific Ocean in the State of Nayarit, forming part politically of the Municipality of Santiago Ixcuintla. It is located at $21^{\circ} 54^{\prime} 21^{\prime \prime}$ north latitude and at $105^{\circ} 28^{\prime} 31^{\prime \prime}$ west longitude, at an average altitude of 5 masl (INEGI, 2017). The island of Mexcaltitan has an oval shape with a perimeter of 1000 meters and a diameter of approximately 400 meters in length from north to south and 350 meters in width from east to west (Arana and Lopez, 1995: 9).

Its streets: two in a north-south direction, two in the east-west, an intermediate one between the western part of the latter and one more following its perimetral contour; the dimensions of its streets vary between 3 and 4 meters approximately of width, with the exception of the surrounding street, that measures 8 meters of width approximately. Most streets have high sidewalks that serve as channels in the periodic floods of the waters of the lagoon, as well as protection to prevent water from entering homes.

The climate on the island of Mexcaltitan is of the warm subhumid type with a regime of rains between June and October and of greater intensity in July and August, that cause an elevation sometimes considerable of the levels of the water that floods the different islets, including the island of Mexcaltitan. In June there is an average annual temperature of $26{ }^{\circ} \mathrm{C}$ to 28 ${ }^{\circ} \mathrm{C}$, with an annual average maximum temperature of $30{ }^{\circ} \mathrm{C}$ to $34{ }^{\circ} \mathrm{C}$. The direction of the winds is from northwest to southwest, with moderate winds.
The island of Mexcaltitan is part of the Marismas Nacionales, that have an area of approximately 200,000 hectares with wetlands, sand coasts, estuarine waters, swamps, mangrove forests, brackish coastal lagoons and water courses. In the coastal plain there is an abundance of inland water or water reservoirs, which is why it has been called the estuarine zone of Nayarit. It is formed mainly by estuaries, which together with the waters that come from the mouth of several rivers and streams, constitute lagoons that cover an area of $920 \mathrm{~km}^{2}$.

This region has 113,000 hectares of mangroves and estuaries (15-20\% of all mangrove swamps in the country and the largest of its kind on the Pacific coast), small timber forest forests (cedars, oaks, others), non-timber (oil palm, water coconut palm, white mangrove, red, black and chinese) and pasture (RHRAP, 2009). Nayarit mangroves are the most extensive in the Mexican Pacific, especially the TeacapanAgua Brava/Marismas Nacionales-San Blas. These ecosystems are the most productive. The main ecological factors that determine its presence are temperature, saline soils, silt and brackish or salt water.

In general, the current vegetation is tropical savanna, mangrove, palmar, medium subperennifolia forest, induced grassland that emerges spontaneously when the original vegetation, halophytic and aquatic vegetation is eliminated; vegetation of coastal dunes is dominated by creeping plants (Ipomoea prescaprae). The red Mangrove (Rhizophora mangle) is an evergreen tropical tree that is found specifically on the shore of coastal lagoons and brackish estuaries. It is located in streams of water and its salinity goes from hypersaline to brackish. The white Mangrove (Laguncularia racemosa), which mixes with the last examples of red mangrove, and becomes more abundant inland on raised soils, where tidal floods are less frequent. While in progression to the most frequently flooded sites, towards the weaker salty soils, less impregnated with water and more closed, dominates the black Mangrove (Avicennia germinans), which is considered dominant in the edges of coastal lagoons formed by depressions parallel to the Nayarita coast (CONANP, 2017). The Palmar or Orbignya forest occurs in disturbed sites, near the coast, on deep and well-drained sands. The dominant species is coconut oil palm (Orbignya guacoyule). Halophytic vegetation is located along the coast, at altitudes below 10 masl, on flat land subject to marine flooding and which have depressions in which the accumulation of salts is high and the drainage is slow. 
The most common species of halophilic plants are Salicornia spp., Batis spp., Sesuvium portulacastrum, Suaeda brevifolia, $S$. ramosissima, Salicornia europea.

Currently, the fauna is classified as Neotropical, is diverse and presents a considerable number of endemic, migratory, endangered and economically important species. Among the relevant species is the jaguar (Panthera onca), river crocodile (Crocodylus acutus), cotorra guayabera (Amazona finchii), green macaw (Ara militaris). In the region, 98 species of mammals have been recorded. At least twelve species are endemic to Mexico and nine are in danger of extinction. These include the river otter (Lutra canadiensis), wild boar (Tayassu tajacu), puma (Puma concolor), jaguar (Panthera onca), mountain lion (Linx rufus), ocelot (Leopardus pardalis), margay (Leopardus wiedii) and white tailed deer (Odocoileus virginianus).

The reserve is very attractive for birds, estimated between 300 and 400 species, that represent $40 \%$ of the total birds that exist in Mexico, have been counted more than 110 thousand beachers in a season, $10 \%$ of the winter population of Avoceta (Recurvirostra americana) and $5 \%$ of the total population of reddish (Calidris canutus roseelari) is present, besides being the southernmost population of the species. It is also part of one of the three most important transcontinental migratory routes (CONANP, 2017).

This coastal plain is furrowed by numerous rivers and streams that are born in the Sierra Madre Occidental and flow into the various lagoons or the Pacific Ocean. The main rivers that cross the region from North to South are, the Baluarte, Cañas, Acaponeta, San Francisco, Rosamorada, Bejuco, San Pedro, Rio Grande de Santiago and San Blas or Sauta. Communicated to the Pacific Ocean by the Boca de Cuautla, El Colorado and the deltas of the Santiago and San Pedro rivers. The island is located in the lagoon of Mexcaltitan, fed by the San Pedro river and by the sea that penetrates through the Mouth of Camichin located on the Pacific coast to 17.5 kilometers from the island. Access to the island is by land communication to the piers, from which you can reach the island only by water in motor boats or canoes.

The Batanga pier, located to the south of the island, is the one with the highest traffic, 6 $\mathrm{km}$ from Mexcaltitan, and to the north the Tinaco pier, smaller than the previous one, is only $2 \mathrm{~km}$ from the island.
The town of Mexcaltitan has a population of 818 inhabitants, of which 434 are men and 384 women, according to the 2010 INEGI census. Its population has as its main activity fishing, in the estuary area that surrounds the island there is fishing for various species of scales among which are snapper, sea bass, mojarra, curvina, constantino, sierra and lisa; and in the zone that surrounds the island year by year the shrimp are harvested, for what is its main source of economy.

Another economic activity is tourism, to whom offer the service of boats to transport the visitors to the island, also they offer tours by the canals and estuaries. Currently the island has basic services such as its own potable water network and drainage network, and in its vicinity a treatment plant is located where only the primary treatment is done.

The electric power line arrives from Santiago, crosses the lagoon, crosses the town behind the church and passes through the square to cross the lagoon to the opposite shore where the jetty of Tinaco is. It also has telephone network and internet. All supplies are purchased off the island and are transported by boat.

The island of Mexcaltitan, declared an area of historical monuments, comprises an area of approximately 0.090 square kilometers, depending on the natural conditions of the site.

It consists of 20 blocks comprising buildings of historical value of which one is destined for religious worship, being the temple of San Pedro and San Pablo, as well as buildings designated for educational purposes, welfare services, civil and military authorities.

The remaining buildings are privately owned buildings and the central square. The most representative buildings are the parish, built in the mid-nineteenth century with a neoclassical repertoire, the ejidal commissariat, the museum and the portals (Diario Oficial de la Federacion, 1986). 


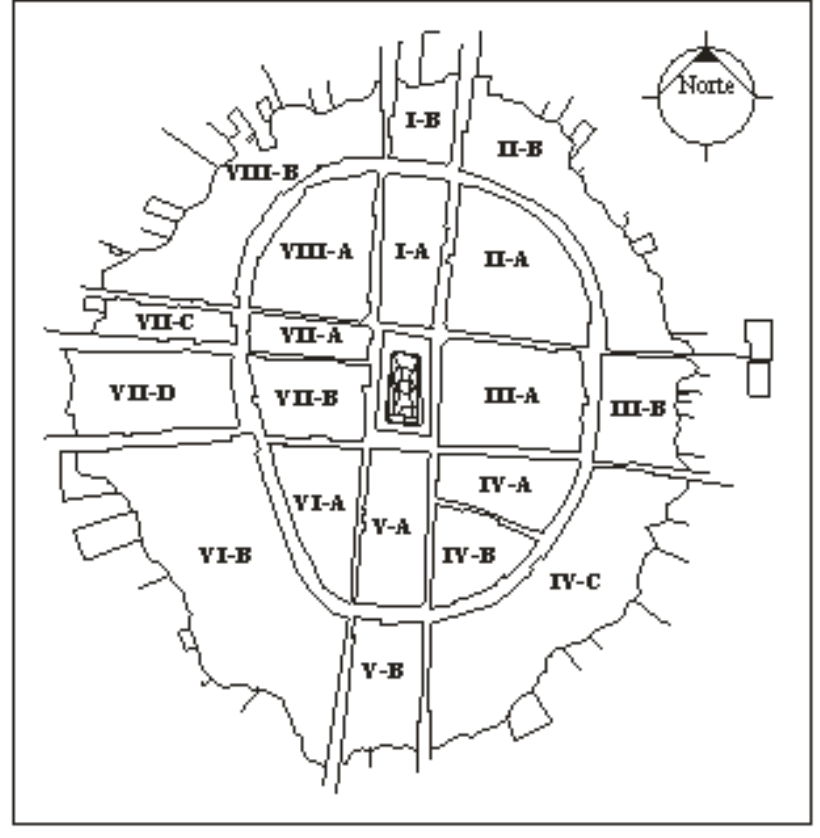

Figure 2 Urban trace of the island of Mexcaltitan, $c a .1980$ Source: redrawn with base in https://es.wikipedia.org/wiki/Mexcaltitán\#/media/File.D Digital:Mexcaltitan1980_20x20.jpg

Digital edition. Eduwiges Hernandez B.

The urban pattern of Mexcaltitan, against what we supposed at first, is different with respect to Tenochtitlan.

The reason for this is that we initially observe in both settlements the same mythicalcosmogonic structure (the cross of the four courses and its centre, the myth of the bird devouring a serpent on an islet in the middle of the lake $)^{17}$ which may possibly continue to be sustained, although, as Monnet (1991: 26) rightly states, in formal terms "it differs sensibly" since in the first case the cross is formed with four axes that two in two intersect perpendicularly, generating eight principal peripheral sectors sorrounding the central open space, ${ }^{18}$ to whose square the main streets converge, "urbanistic concept typical of the European Renaissance and of the Spanish colonization"; ${ }^{19}$ while in the second case the intersection of the two axes that form the cross occurs just above the site of the Templo Mayor, generating four sectors.
In addition, as Monnet points out, in Mexcaltitan the ring road, by its circular form, is associated rather with urbanistic and architectural traditions of the pre-Hispanic west (Monnet, 1991: 26), that is to say with the Teuchitlan tradition, to which the near archaeological site of Los Toriles in Ixtlan del Rio would belong, although this ring feature, not so frequent, was not completely absent in the rest of Mesoamerica, in spite of the fact that it is a terrestrial, rather than insular.

\section{A model for Mexcaltitan. First approximation}

For the mythology of the island. In accordance with the theoretical device given for the conceptual apparatus of Gilbert Durand, we summarize an exercise in the translation of the above categories and concepts, in the manner of a free reading that attempts to offer an interpretation of the symbolism of the urban trace of Mexcaltitan as a tangential approach to the object of study that we are really interested in: the subjective construction of the urbanarchitectural patrimonial appropriation sense and the mythical geography of the island of Mexcaltitan in distinct ego and exocentric communities. Of course, our reading falls within the exocentric gaze, reserving the double ego and exo look of other communities to our last theoretical device (the geography of interpretation), which we are just beginning to work on.

According to the analysis, our archetypology proposes three archetypal images that summarize the symbolism that we give to the trace of the island of Mexcaltitan, without prejudice to the possible meanings granted to it by the community of Chinese descendants, that of mestizo residents, that of tourists and eventually that of the Huichol ethnic group, and even that of other historians, archaeologists or anthropologists who are behind the historical, non-mythical origin of this curious urban configuration.

\footnotetext{
${ }^{17}$ According to Romero Gallardo (quoted at Monnet, 1991: 26), Huitzilopochtli would have given to the Aztec priest who would lead the pilgrimage, a stone that would "help him remember the sign", for a heron was carved on a serpent. A work that recreates the debate in this regard is that of Jesus Jauregui (2004: 56-61). Phil C. Weigand (1994: 363-381) has also echoed the debate with his "Rerum Novarum: the myth of Mexcaltitan as Aztlan".

${ }^{18}$ Generating two more subsectors in the west and southeast inner sectors, and even without considering the outer areas to this structure.
}

ISSN: 2444-3204

ECORFAN ${ }^{\circledR}$ All rights reserved
${ }^{19}$ In fact, some sources claim that the site named Mexcaltitan "is not mentioned before 1550 in the known colonial documents" (which were, in this case, the cartography and the suma de visitas), and in 1619 "the place is described briefly for the first time, as a grouping of 25 or 30 houses" (Monnet, 1991: 25). There is another reference on "Mezcaltitlan" in the Public Library of the State of Jalisco Juan Jose Arreola, Main Fund, Civil Branch, Real Hearing, Box 465, Record 20, 1695-1730, 12 pages.

SIFUENTES-SOLÍS, Marco \& GONZÁLEZ-LEFFT, Gabriela. Towards an interpretative model of Mexcaltitan in the insular universe. First approximation. ECORFAN Journal-Spain. 2020 
These images are those of the port, the ring and the citadel (a very Platonic archetype), whose semic condensation or, to put it in words of Durand, whose constellations of meaning can be opened as much as the creative imagination allows, although to the point to avoid an emptying of unacceptable meaning and aware of the risk involved in a term-by-term reading of Durand's theoretical framework.

The Port. In this way, the first archetypal image will be that of the piers, critical points of contact of and with the island, that although they exist by all the surrounding perimeter, are four structurally main, located precisely at the ends of the axes that define the structure of the cruciform vial of the island, that is to say, the four pairs of streets that, like swords or knives, depart the village in eight peripheral sectors and a center, thus related to the cardinal points (metaphor of the cosmos). The island is a microcosm that nevertheless remains open to contact with the outside, to the four directions, that is to say to the planetary and even cosmic ecumene.

The piers, the port, symbolize at the same time all kinds of antithetical figures that tend to separate and distinguish from the unknown, to define what is above (the luminous, the island) with respect to its aqueous substrate (the sea), ${ }^{20}$ to distinguish the exterior from the interior, to communicate polemicly both: the outside and the inside, the tension between the inner self and the other outside or between the egocentric communities living on the island and the exocentric, as well as tourists like any other nonresident stranger (the Huichol ethnic group, researchers). Its principle will be that of contradiction; the axial symmetry, bilateral or reflective, its geometrical quality, as manifested in the layout of the rectilinear streets, mirrored with respect to the two crossed axes that mark the north-south and east-west courses.

When talking about the imaginary insular anti-utopic, Oscar Galindo observes that "the islander perceives its space sometimes, no longer as a place of dreams, but of confinement. Hence the island's irreversible vocation. Let's say that the islander's utopia is usually continental" (Galindo, 2000: 170).

\footnotetext{
${ }^{20}$ In Huichol myths the sea is the habitat of "all manner of dangerous monsters", such as whales, winged serpents, vampires and chupacabra; that is to say, the kind of beings proper to the Durand's diurnal regime (Neurath y Pacheco, n.d.: 5).

${ }^{21}$ In the tradition of huicholes, when sea monsters (a water snake for example, nictomorph symbol of diurnal regime, according to Durand) leave the sea, they do it to "devour people or to flood the world". Note that in Mexcaltitan with some frequency, in the rainy season, water floods both the circular street and the rectilinear (Neurath y Pacheco, n.d., 5).

He also adds that "Faced with the danger of the disintegration of subjectivity, the characters are settled in that space [the island], which serves as both a refuge and a stage" (Punte, 2013: 131). From the shores the surrounding luminosity is better seen until the green horizon, which is difficult being in the interior of the island, between the buildings; the sunset is the prelude to the region of unfathomable darkness, the realm of fear, the kingdom of the death of the sun, which, if it pleases the gods, reappears the next day, illuminating the earth again. The ring. The street that surrounds the village and protects its inhabitants, but at the same time welcomes the strangers in a synthesis in which the "contact of realities that appeared different and distant" is realized (Gracia, 2001: 149), constitutes another of the memorable features of the island. By belonging to the Nocturnal regime of images, defined by cyclic time (such as the summer floods that turn the Mexcaltitan's streets into waterways), ${ }^{21}$ it delimits both the inside and the outside, the intimate fraternal and the distant near: the fear of the dark forces floods of architecture colour, that united with the green interior produces a surrounding environment resembling a redoubt of tranquility and happiness (metaphor of paradise). Thus, the second archetypal image will be the ring, whose principle will be that of the coincidentia oppositorum, and equidistance and rotational symmetry, their geometrical qualities, accused by the meager dimensions of the place: "the island, when small, gives the sensation of a finite and describable space that can be perceived, traversed and measured individually, which allows their appropriation not only visual but personalized" (Ainsa, 2000: 8). Each resident, each tourist, recreates his locus amoenus, his ideal setting, the cozy maternal womb, his particular appropriate eden, and appropriate according to his longing for happiness, since "without the isolation that a small island brings, one does not get the perception of disconnection from the daily sufferings" (Cardona, Azpelicueta y Serra, 2015: 728) hence "The search for the paradisiacal island can be seen in the predilection for island tourist destinations" (Cardona, Azpelicueta y Serra, 2015: 717). 
Hence also that if you leave that, the uterus becomes the fall in the world of exteriority.

However, the proximity, the sense of the siege can lead to problems: "People who can not physically or psychologically escape the island or its past tend to objectify the other and the convergence of people with this attitude arises the conflict, giving situations of masochism, sadism or indifference, and the scapegoat is the fear of the human condition of one's own conscience" (Bonetto, quoted at Cardona, Azpelicueta y Serra, 2015: 724). Fear again. It will have to be exorcised.

The Citadel. The siege is transposed, equidistant, the island within the island, the place of peace, harmony and veneration, the sacred space in which myth is reiterated through rituals (not in vain, as stipulated in the famous document of Philip II, the square and the church were to be drawn "in square shape" and "full block", respectively, "so that no other building is attached to them, but the one belonging to its comfort and adornment"); ${ }^{22}$ and more than that, this place recovers heroized, for, as Diez de Velasco affirms, "thanks to the myth, the alchemy of overcoming the sad and degenerate contemporary age is transmuted into the prestigious heroic age" (Diez, 1997: 9); interior space as geometric and symbolic center protected and protective (metaphor of the refuge).

The centrality condenses the point of communication with the mystery, with the sacred, impels to feel "center" of the myth, but a myth renewed, recreated, readjusted, updated to the present circumstances, since the myth does not subsist in the time in pure state -even at the time it was written- (Diez, 1997: 5).
The myth, ${ }^{23}$ through its rituals, is transformed, secularized, trivialized, but there remains a region that is difficult to think is franqueable: the will to believe "centre" (or "cradle of Mexicanness" in the case at hand) and "to be devoured" by the sacred unfathomable (Castro, 2012: 59).

The archetypal image will be the citadel, with emblematic buildings of celestial and earthly powers, symbolizing the spiritual shelter (and material?) or the celebrated tradition (the local museum) and in which they are confused (never melt) the resident and the stranger who are tolerated harmoniously but interested in a tacit contract, in a sort of identity complicity.

So, its principle will be the consonance, the concord, while the central symmetry is its geometric quality, for all converge to the innermost inward. The table showing here attempts to capture the above.

It may be perplexing to make analogies between Durand's model and our first approach to Mexcaltitan's analysis, and - given our research lacking primary sources, which would be the subject of another project and not the present one - may even be an exercise as much sterile as overextended, but at least has the value of trying to establish an alternative meaning through iconographic redundancies of the urban trace beyond the politically interested myth, although with the point of connection of cyclical temporality "that refers to Mother Earth as a common centre of all beings. This is an ontology of successive circles, spheres, and closures; of the circumference as a perfect and finished form and, at the same time, of myths that convey the notion of cyclical time that is characteristic of the seasons, the rhythm and the plot of death". ${ }^{24}$

${ }^{24}$ Castro (2012: 53 y 57) points out that in Durand redundancy "operates ritually when it comes to the gestural; is mythical when it involves the linguistic and is iconographic when applied to images".

\footnotetext{
${ }^{22}$ Clauses 112 and 119 of the Ordinances on Discovery, New Population and Pacification of the Indies, in: http://www.biblioteca.tv/artman2/publish/1573_382/Orde nanzas_de_Felipe_II_sobre_descubrimiento_nueva_1176 .shtml. Consultation: July 9, 2017.

${ }^{23}$ It is surprising that in the Huichol myths, the place of origin of this ethnic group is considered as the center of a world where the land "floats on the sea, like a large island, under the consideration that water surrounds the entire surface of the earth"; the sea was the underworld, place of the ancestors; when they left it, the world was dark, the night was eternal (nocturnal regime). From the ritual sacrifice the god-men are reborn, the light is reborn (diurnal regime) (Neurath y Pacheco, n.d.: 3-4).

ISSN: 2444-3204

ECORFAN ${ }^{\circledR}$ All rights reserved
}

SIFUENTES-SOLÍS, Marco \& GONZÁLEZ-LEFFT, Gabriela. Towards an interpretative model of Mexcaltitan in the insular universe. First approximation. ECORFAN Journal-Spain. 2020 
Image Organizing Structures

\begin{tabular}{|l|l|l|}
$\begin{array}{l}\text { Diurnal Regime of } \\
\text { the Images }\end{array}$ & \multicolumn{2}{|l|}{ Nocturnal Regime of the Images } \\
\hline $\begin{array}{l}\text { Schizomorphic } \\
\text { Structures }\end{array}$ & $\begin{array}{l}\text { Synthetic } \\
\text { Structures }\end{array}$ & $\begin{array}{l}\text { Mystic } \\
\text { Structures }\end{array}$ \\
\hline
\end{tabular}

\begin{tabular}{lll} 
Structures & Structures & Structures \\
\hline Dominant Reflections and Action Schemes
\end{tabular}

\begin{tabular}{|c|c|c|}
\hline To Distinguish & To Unite & To Confuse \\
\hline $\begin{array}{l}\text { The metaphor of } \\
\text { the cosmos } \\
\text { Axial Symmetry }\end{array}$ & $\begin{array}{l}\text { The metaphor of } \\
\text { paradise } \\
\text { Rotational } \\
\text { Symmetry }\end{array}$ & $\begin{array}{l}\text { The metaphor } \\
\text { of the sacred } \\
\text { refuge } \\
\text { Central } \\
\text { Symmetry }\end{array}$ \\
\hline
\end{tabular}

Table 1

Source: reworking from Tome (1987: 19) and Ocampo (2008: 34-40).

Digital edition: Eduwiges Hernandez B.

\section{Acknowledgments}

We appreciate the support of CONACYT for the scholarship granted to the co-author of this article.

\section{Conclusions}

In this article we have dealt with the mythical aspect of Mexcaltitan considering elements such as: 1) the theme of the insular imaginary from a tight symbolic hermeneutic perspective, both in the historiography (the utopian narrative), the mythology in itself (the fantastic story) and in the ethnography (the story of travels); 2) the appropriate model for the theoreticalmethodological approach of this imaginary from our "point of observation", for which we turn to the anthropological structures of the imaginary of G. Durand; and 3) we briefly advance some theoretical assumptions of the geography of interpretation, and some J. Monnet's criticalanalytical elements in an attempt to understand the extraordinary peculiarity of Mexcaltitan's urban trace in a first reading. In the future, a second approximation of the subjective processes of appropriation of the urbanarchitectural patrimonial space and of the mythical geography by ego and exocentric communities must be made. This second sight propperly will constituite the ethnography of the island.

\footnotetext{
${ }^{25}$ According to Jose E. Marquez, quoted by DiazMontexano (2010), the wells and trenches of circular forms associated with towns, whose oldest vestiges belong to the end of the Neolithic period, gradually spread through the Atlantic "facade", although they were losing the condition of permanently inhabited territories. Weigand (1996: 185-245) suggests that the early phases of

Through the archetypal images of the port, the ring and the citadel, in this article we try, therefore, to open the interpretation of the island of Mexcaltitan towards other paths, rather than completely replacing, are linked to the discourse of the myth of origin (Aztlan = Mexcaltitan, "cradle of Mexicanness"), constructing the idea of an even more primordial spatial archetype: the urban structure of the mythical insular imaginary of classical Greek antiquity, which, however, is not the same as affirming, abusively, the historical existence of direct contacts between the Greeks and the ancient Aztecs of Aztlan, but rather to emphasize that in the phenomenology of religion, in the universe of psychology or in the world of creative imagination, there could be, in the case of the insular universe, and only in it, a same spatial structure -at least similar- of the relationship between the human being and his environment, or a common cultural substratum, to put it in Ekman's words (Ekman, 2009: 294), when geographical conditions are in a way similar, in this case islands. Our paper aims that the concentric urban pattern was relatively common in lakes, the sea and even terrestrial environments, in some pre-Hispanic and European cultures (Mythological Greece, the historical Spain of the Chalcolithic and the Bronze Age, the "causedwayed Enclosures" of some Anglo-Saxon countries, and the Teuchitlan tradition) (Diaz-Montexano, 2010). ${ }^{25}$ The reason for this still remains open to research, and even more so its connection with the myth of Atlantis, which also remains without conclusive and definitive scientific demonstration.

The island, in short, is separation and its centre is return (Castro, 2012: 59). We must remember the previous warning that our reading has been set from our exocentric perspective, so that to that extent must be judged. This first interpretation, which in any case must be taken as a hypothesis to be contrasted with that of the other ego and exocentric communities (second approach, in progress), tries to fit in the line of Durand, although, quoting Gracia, does not pretend to become a convention, because "every «convention», although animated by the best intentions of «symbolic defense» is fatally dogmatic", as a symbol does not mean, but evokes (Gracia, 2001: 142-143).

the Teuchitlan tradition, from the Preclassic to the early Classic, were dominated by concentric urban patterns that, over time, under the influence of the Bajio and the northcentral Mexico, would have been gradually replaced by reticular patterns, which shows that the circle could have been an even more primitive archetype than the square or rectangle, at least in the West of ancient Mexico.

SIFUENTES-SOLÍS, Marco \& GONZÁLEZ-LEFFT, Gabriela. Towards an interpretative model of Mexcaltitan in the insular universe. First approximation. ECORFAN Journal-Spain. 2020 


\section{References}

Ainsa, Fernando (2000). "Las ínsulas de «tierra firme» de la narrativa hispanoamericana: entre la memoria y la esperanza", en Carmen Alemany Bay et al. (Eds.), La isla posible, España: Biblioteca Virtual Universal, pp. 7-15.

Alemany Bay, Carmen et al. (Eds.) (2000). La isla posible, España: Biblioteca Virtual Universal.

Anguiano, Marina (1992). Nayarit: costa y altiplanicie en el momento del contacto, México: UNAM.

Arana, R. y Lopez, P. (1995). Mexcaltitán, crónica de su historia. Xalisco, Nayarit, México: Universidad Autónoma de Nayarit.

Cardona, Jose Ramon; Azpelicueta, Maria del Carmen; Serra, Antoni (2015). "El mito del paraíso perdido en la definición del destino turístico", en Estudios y Perspectivas en Turismo, Vol. 24, No. 3, pp. 715-735.

Castro Merrifield, Francisco (2012). "Gilbert Durand y el método arquetipológico", en Acta Sociológica, No. 57, enero-abril, pp. 51-64.

CONANP (2017). "Reserva de la Biósfera Marismas Nacionales Nayarit". La información en: http://marismasnacionalesnayarit.conanp.gob.mx/flora. Consulta: agosto 2 de 2017.

Cruz Andreotti, Gonzalo (1994). "La historia (antigua), las islas míticas y las Canarias", en Baetica. Estudios de Arte, Geografía e Historia, No. 16, pp. 241-245.

Diaz-Montexano, Georgeos (2010). “¿La ciudad más antigua de Europa? Patrón urbanístico Atlante en las más antiguas ciudades del occidente", junio, en Paperblog [on line]: http://es.paperblog.com/la-ciudad-mas-antiguade-europa-patron-urbanistico-atlante-en-lasmas-antiguas-ciudades-del-occidente-1996901. Consulta 9 de julio 2017.

Diaz-Montexano, Georgeos (2014). “Aztlán y Atlantis. ¿Descendían los aztecas de una isla en medio del Atlántico?", en Diario Ideal, 26 de noviembre,

en: http://blogs.ideal.es/atlantida/2014/11/26/aztlan -y-atlantis-descendian-los-aztecas-de-una-islaen-medio-del-atlantico. Consulta: 10 julio 2017.

Diez de Velasco, Francisco (1997). "El mito y la realidad", en Diez de Velasco, M. Martinez y A. Tejera (Eds.). Realidad y Mito, España: Ediciones Clásicas, pp. 19-43.
Durand, Gilbert (2000). La imaginación simbólica, Argentina: Amorrortu Editores.

Durand, Gilbert (2004). Las Estructuras Antropológicas del Imaginario: introducción a la Arquetipología General, México: FCE.

Ekman, Chjalmar J. (2009). "La historia en torno al mito: algunos aportes teórico-metodológicos desde la historia cultural", en Presente y Pasado. Revista de Historia, Año 14, No. 28, juliodiciembre, pp. 285-304.

Elie, Serge D (2012). "The Production of Social Science Knowledge beyond Occidentalism: the quest for a post-exotic anthropology", Third World Quarterly, 33:7, 1211-1229.

Fernandez Robbio, Matias Sebastian (2010). "La travesía de Yambulo por las Islas del Sol (D.S. II.55-60). Introducción a su estudio, traducción y notas", en MORUS - Utopia e Renascimento, No. 7, pp. 27-41.

Galindo, Oscar (2000). "El imaginario insular antiutópico en la poesía chilena reciente", en Carmen Alemany Bay et al. (Eds.), La isla posible, España: Biblioteca Virtual Universal, pp. 170-178.

Garcia Castro, Rene (Coord. y Ed.) (2013). Suma de visitas de pueblos de la Nueva España, 1548-1550, Toluca: Universidad Autónoma del Estado de México.

Gracia, Isabel (2001). "La hermenéutica del lenguaje: Gilbert Durand", en Jaime D. Parra (Coord.), La simbología. Grandes figuras de la Ciencia de los Símbolos, España: Ed. Montesinos, pp. 139-154.

INEGI (2017). "Marco Geoestadístico Nacional", en: http://www.inegi.org.mx/geo/contenidos/geoest adistica/consulta_localidades.aspx. Consulta: agosto 2, 2017.

Iriarte, Helena (2005). "Ciudades míticas y literarias", en Revista de Arquitectura, Vol. 7, Universidad Católica de Colombia, pp. 24-27.

Jauregui, Jesus (2004). “Mexcaltitán-Aztlán. Un nuevo mito", en Arqueología Mexicana, No. 67, mayo-junio, pp. 56-61.

Killuminati, Felix (n.d). "La Atlántida, el continente perdido", en: http://www.conspiracioneskilluminati.com/201 3/02/atlantida-el-continente-perdido.html, consulta: 23 junio 2017.

SIFUENTES-SOLÍS, Marco \& GONZÁLEZ-LEFFT, Gabriela. Towards an interpretative model of Mexcaltitan in the insular universe. First approximation. ECORFAN Journal-Spain. 2020 
Martinez Hernandez, Marcos (2010). "Islas legendarias (II)", en FORTVNATAE, No. 21, pp. 55-74.

Martinez Hernandez, Marcos (1997). "Islas míticas", en F. Diez de Velasco, M. Martinez y A. Tejera (Eds.), Realidad y Mito, España: Ediciones Clásicas.

Monnet, Jérôme (2011). “La interpretación del mundo, de la representación a la acción: una mirada desde la geografía francesa”, en G. Capron, C. Icazuriaga Montes, S. Levi, E. Ribera Carbo y V. Thiébaut, La geografia contemporánea y Elisée Reclus, México: Publicaciones de la Casa Chata, pp. 135-159.

Monnet, Jérôme (1995). Usos e imágenes del Centro Histórico de la ciudad de México, México: Centro de Estudios Mexicanos y Centroamericanos-Departamento del Distrito Federal.

Monnet, Jérôme (1991). “Mexcaltitán, territorio de la identidad mexicana: la creación de un mito de origen", en Vuelta, Vol. 15, No. 171, febrero, pp. 25-30.

Montesdeoca, Jose Manuel (2000). "Los islarios de la época del humanismo: el de insulis de Domenico Silvestri. Edición y traducción", España: Universidad de La Laguna, tesis doctoral, 684 págs.

Morales, Gracia Ma. (2000). "Desde la isla al cosmos: la función del pensamiento míticomágico en las sociedades primitivas", en Carmen Alemany Bay et al. (Eds.), La isla posible, España: Biblioteca Virtual Universal, pp. 283-296.

Moret, Pierre (2011-12). "Honorato de Lérins, Heracles y las islas errantes", en CuPAUAM 3738 , pp. 455-464.

Muñoz Jimenez, J. M. (1991). Aproximación al urbanismo griego: la ciudad como obra de arte. Madrid: Estudios Clásicos, Tomo XXXIII, Número 100.

Navarro, Maria Isabel (2016). "Utopías: lugares y no-lugares en la construcción visual de la utopía”, XIV Coloquio Internacional de Geocrítica. Las utopías y la construcción de la sociedad del futuro, Barcelona, mayo, 30 pág.

Neurath, Johannes y Pacheco, Ricardo Claudio (n.d.). "Pueblos indígenas de México y agua: huicholes (wixarika)", en Atlas de culturas del agua en América Latina y el Caribe, p. 5, en: http://www.unesco.org.uy/ci/fileadmin/phi/agua ycultura/Mexico/05_Huicholes.pdf.
No author (n.d.). "La Atlántida en los

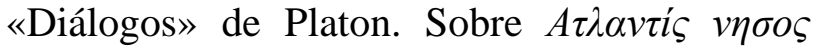
(Atlantís nêsos) o la isla-península de la Atlántida",

en: http://www.culturandalucia.com/TARTESOS/P LATON_DIALOGOS_CRITIAS_ATLANTID A.htm, consulta: 28 mayo 2017).

No author (n.d.). "La civilización y el Continente perdido de la Atlántida", en: http://www.borala.site/continente-perdido-deatlantida, consulta: 23 junio 2017.

Ocampo, Luz Stella (2008). "Lectura de ciudad en la obra «Pereira visión caleidoscópica» de Rigoberto Gil Montoya", tesis de licenciatura, Colombia: Universidad Tecnológica de Pereira, 249 págs.

Oïffer, Alicia (2011). "El Islario general de todas las islas del mundo (1560) de Alfonso de Santa Cruz o la ciencia cosmográfica en la España de Felipe II: en el Nuevo Mundo, el Caribe insular", pp. 169-187; versión reelaborada en español de un trabajo en francés titulado «La connaissance de la Terre dans l'Espagne du XVI ${ }^{\mathrm{e}}$ siècle à travers l'Islario general de todas las islas del Mundo (1560) d'Alfonso de Santa Cruz : 1'exemple des Petites Antilles», Dir. Bernard Grunberg, éd. L'Harmattan, Cahiers d'Histoire de l'Amérique Coloniale, No. 5 Paris.

"Ordenanzas sobre Descubrimiento, Nueva Población y Pacificación de las Indias", en: http://www.biblioteca.tv/artman2/publish/1573 _382/Ordenanzas_de_Felipe_II_sobre_descubri miento_nueva_1176.shtml. Consulta: 9 julio 2017.

Pellicer, Rosa (2000). "Islas singulares: Amazonas y Jauja", en Carmen Alemany Bay et al. (Eds.), La isla posible, España: Biblioteca Virtual Universal, pp. 354-365.

Peri Rossi, Cristina (2000). "La isla interior", en Carmen Alemany Bay et al. (Eds.), La isla posible, España: Biblioteca Virtual Universal, pp. 379-394.

Punte, Maria Jose (2013). “«Locus amoenus» de la contemporaneidad: la isla como metáfora de la escritura”, en RILCE, 29 (1), pp. 115-135.

Red Hemisférica de Reservas para Aves Playeras, RHRAP (2009). "Marismas Nacionales". La información en: http://www.whsrn.org/es/perfil-de-

sitio/marismas-nacionales. Consulta: agosto 2, 2017.

SIFUENTES-SOLÍS, Marco \& GONZÁLEZ-LEFFT, Gabriela. Towards an interpretative model of Mexcaltitan in the insular universe. First approximation. ECORFAN Journal-Spain. 2020 
Tome, Mario (1987). La isla: utopía, inconsciente y aventura. Hermenéutica simbólica de un tema literario, España: Universidad de León.

Weigand, Phil C. (1996). "La evolución y ocaso de un núcleo de civilización: la tradición Teuchitlán y la arqueología de Jalisco", en Eduardo Williams y Phil C. Weigand (Eds.), Las cuencas del Occidente de México (época prehispánica), El Colegio de Michoacán-Centro de Estudios Mexicanos y CentroamericanosInstituto de Investigaciones Científicas para el Desarrollo en Cooperación, México.

Weigand, Phil C. (1994). "Rerum Novarum: el mito de Mexcaltitán como Aztlán”, en Eduardo Williams y R. Novella (Coords.), Arqueología del Occidente de México: nuevas aportaciones, Zamora: El Colegio de Michoacán, pp. 363-381. 